\title{
KEMAMPUAN GURU DALAM MELAKSANAKAN PAKEM DI SEKOLAH DASAR
}

\author{
Maratun Nafiah, Gusti Yarmi, dan Dudung Amir S.
}

\begin{abstract}
The student centered learning is the learning method that activates the students and could be carried out by applying active, creative, effective, and joyfull learning (PAKEM). This qualitative research aims of findings out PAKEM is in implemented at four elementary schools in Bali and Central Java provinces. The research was carried out from February to October 2007, concludes: (1) a lot of conventional approach (teacher-centered) are still practical in the classroom; (2) the classroom situations doesn't reflect any active, creative, effective, joyfull learning (PAKEM) characteristics; (3) none of student's work show up on the classroom wall; (4) the classroom is not fully explored to be a learning resource; and (5) instructional methods use are dominated by the teacher. In addition it is also important to know that the learning process doesn't take benefit of the existing facilities with in this situation, the group study, self study, and the problem based learning are not practised optimally neither the use of classs paces as the source of learning. More over, the methods being used were toll the one way instructional mode. It was also important to be mentioned that there were no usage of the sourrounding atmosphere as the leasy source. The optimalization of the group study, self study and the problem based learning hadn't been achieved yet.
\end{abstract}

Keywords: student-centered learning, teacher-centered learning, instructional model.

\section{PENDAHULUAN}

\section{Latar Belakang Masalah}

Pembelajaran merupakan salah satu unsur penentu baik tidaknya lulusan yang dihasilkan oleh suatu sistem pendidikan. Ia ibarat jantung dari proses pembelajaran. Pembelajaran yang baik cenderung menghasilkan lulusan dengan hasil yang baik pula. Demikian pula sebaliknya, jika pembelajaran yang dilaksanakan tidak baik maka akan dihasilkan lulusan yang jauh dari berkualitas (Anon, 2006:68).

Lulusan yang baik dari sebuah lembaga pendidikan akan mempengaruhi karakter suatu bangsa. Agar karakter bangsa yang dihasilkan menjadi baik diperlukan pembelajaran yang efektif. Pembelajaran yang efektif dapat melatih kecakapan hidup (life skill) bagi siswanya. Pendidikan kecakapan hidup (life skill educations) adalah pendidikan yang melatih kemampuan, kesanggupan, dan keterampilan yang diperlukan oleh seseorang untuk menjaga kelangsungan hidup dan pengembangan dirinya (Slamet, 2007:5). Kemampuan mencakup daya pikir, daya kalbu, dan daya raga. Kesanggupan sangat dipengaruhi oleh kepentingan, yaitu sesuatu yang dianggap penting oleh siapa dalam bentuk apa. Keterampilan adalah kecepatan, kecekatan, dan ketepatan dalam mengerjakan sesuatu.

Kecakapan hidup yang telah dimiliki akan dapat mewariskan nilai kehidupan yang bermakna bagi siswa tersebut dan akan membentuk karakternya. Karakter yang sudah dimiliki siswa akan membangun karakter komunitas dan karakter komunitas akan membangun karakter bangsa. Dapat ditegaskan pembelajaran dengan pendekatan yang efektif akan menghasilkan karakter bangsa yang baik.

Mengingat besarnya peranan hasil dari sebuah proses pembelajaran maka hal ini perlu menjadi perhatian besar bagi semua orang, terutama guru. Pembelajaran yang efektif artinya pembelajaran yang dapat menghasilkan output yang berkualitas dan memiliki karakter. Hasil dari proses pembelajaran diharapkan tidak hanya sekedar membekali lulusannya dengan pengetahuan yang sifatnya hanya verbalisme. Akan tetapi, diharapkan lulusan yang dihasilkan memiliki kompetensi dan karakter sesuai dengan tuntutan Sumber Daya Manusia (SDM) abad ke-21. Karakter yang harus dimiliki oleh SDM abad ke-21 antara lain siswa yang mampu berpikir kritis, mau bekerja keras, mampu memecahkan masalah, bisa bekerja sama, jujur, kreatif, komunikator yang efektif, dapat dipercaya, mandiri, disiplin, dan suka menolong. Untuk menghasilkan siswa berkarakter seperti tersebut di atas, perlu dirancang dan dilaksanakan pembelajaran yang betul-betul dapat mengembangkan berbagai potensi yang ada dalam diri siswa. Artinya, pembelajaran harus dirancang dengan memilih metode-metode dan kegiatan pembelajaran yang berpusat pada siswa. Dengan pembelajaran 
yang berpusat pada siswa maka segala sesuatu yang berkaitan dengan pembelajaran bertitik tolak pada siswa, mulai dari pemilihan materi, metode, alat peraga atau media, dan kegiatan pembelajaran harus memperhatikan perkembangan siswa.

Jadi, dalam pembelajaran yang bermakna siswa harus diaktifkan melalui kegiatan belajar sambil melakukan. Hal ini sejalan dengan pendapat Dewey, yakni learning by doing. Pembelajaran yang berpusat pada siswa, yaitu yang mengaktifkan siswa dapat diwujudkan melalui penerapan Pembelajaran Aktif, Kreatif, Efektif, dan Menyenangkan (PAKEM). Akan tetapi, sejauh mana penerapannya bagi guru di lapangan tentang PAKEM perlu dilakukan suatu studi atau penelitian.

Berdasarkan pengamatan di lapangan ketika membimbing Program Pengalaman Lapangan (PPL), kenyataannya pembelajaran yang dilaksanakan masih berpusat pada guru (teacher oriented - teacher centered). Segala sesuatu yang berkaitan dengan pembelajaran, guru yang menentukan. Semua materi yang akan dipelajari siswa dijelaskan oleh guru. Paradigma guru pada umumnya tentang kesuksesan membelajarkan adalah apabila dalam proses pembelajaran siswa duduk dengan tenang mendengarkan penjelasan guru. Padahal diketahui bahwa apabila hanya mendengarkan guru tanpa melakukan maka siswa tidak dapat memahami materi yang diberikan. Seperti diketahui dalam konsep belajar bermakna dikatakan $I$ hear and I forget, I see and I remember, I do and I understand (saya dengar dan saya lupa, saya melihat dan saya ingat, saya berbuat dan saya mengerti).

Kenyataan di lapangan, pada umumnya guru di Sekolah Dasar (SD) masih banyak memberikan ceramah. Pendekatan pembelajaran seperti ini menyebabkan hasil belajar di Indonesia masih dipandang kurang baik. Sebagian besar siswa belum mampu menggapai potensi ideal atau optimal yang dimilikinya (Anon, 2006:68). Berdasarkan hal tersebut, yakni tercermin adanya pembelajaran yang masih berpusat pada guru (teacher oriented-teacher centered) dan pembelajaran yang masih menekankan pada pengetahuan, perlu dikaji faktor penyebabnya. Apakah karena ketidakpahaman guru tentang konsep PAKEM atau karena ketidakmampuan guru dalam melaksanakannya. Untuk mengetahui apa yang terjadi, penelitian ini dianggap perlu untuk dilaksanakan.

\section{Identifikasi Masalah}

Berdasarkan uraian di atas, dapat dirumuskan sejumlah masalah yang berhubungan dengan pendekatan pembelajaran aktif, kreatif, efektif, dan menyenangkan sebagai berikut.
1. Bagaimana kegiatan belajar membelajarkan yang digunakan guru dalam mengembangkan PAKEM?

2. Apa saja alat bantu atau sumber belajar yang diperlukan guru dalam mengembangkan PAKEM?

3. Apakah pemilihan metode pembelajaran guru sudah tepat dalam mengembangkan PAKEM?

4. Bagaimana pengalaman belajar yang diperoleh siswa?

5. Apakah pemilihan bahan ajar sesuai dengan karakeristik siswa?

6. Apakah pendekatan pembelajaran yang digunakan guru dalam mengembangkan PAKEM bersifat kontekstual?

7. Bagaimana penilaian yang dilakukan guru?

\section{Tujuan Penelitian}

Tujuan penelitian ini adalah ingin mengetahui kegiatan belajar membelajarkan yang digunakan guru dalam mengembangkan PAKEM, alat bantu atau sumber belajar yang diperlukan guru dalam mengembangkan PAKEM, metode pembelajaran guru dalam mengembangkan PAKEM, pengalaman belajar yang diperoleh siswa dalam pembelajaran, pemilihan bahan ajar yang dilakukan guru, pendekatan pembelajaran yang digunakan guru dalam mengembangkan PAKEM, serta penilaian yang dilakukan guru dalam pembelajaran.

\section{Manfaat Penelitian}

Hasil penelitian ini diharapkan dapat bermanfaat untuk: (1) meningkatkan pengetahuan guru SD tentang PAKEM dan dapat melaksanakan pembelajaran dengan menggunakan pendekatan PAKEM, dan (2) meningkatkan kualitas pembelajaran di SD dengan menerapkan PAKEM.

\section{KAJIAN TEORETIS}

\section{PAKEM}

PAKEM merupakan salah satu pilar dari program Manajemen Berbasis Sekolah (MBSmenciptakan masyarakat yang peduli pendidikan anak) dan program ini merupakan program UNESCO bekerja sama dengan Departemen Pendidikan Nasional.

Aktif dimaksudkan bahwa dalam proses pembelajaran guru harus menciptakan suasana sedemikian rupa sehingga siswa aktif bertanya, mempertanyakan, dan mengemukakan gagasan. Belajar harus merupakan suatu proses aktif dari siswa dalam membangun pengetahuannya, bukan hanya proses pasif yang hanya menerima penjelasan dari 
guru tentang pengetahuan. Pendapat yang senada juga dikemukakan oleh Katz dan Chard dalam Owen (2007) bahwa siswa perlu keterlibatan fisik untuk mencegah mereka dari kelelahan dan kebosanan. Siswa yang lebih banyak duduk diam akan menghambat perkembangan motorik, akademik, dan kreativitasnya.

Siswa usia TK dan SD lebih cepat lelah jika duduk diam dibandingkan kalau sedang berlari, melompat, atau bersepeda. Akan tetapi, dengan belajar yang aktif, motorik halus dan motorik kasar mereka akan berkembang dengan baik. Melalui belajar aktif segala potensi siswa dapat berkembang secara optimal dan memberikan peluang siswa untuk aktif berbuat sesuatu sambil mempelajari berbagai pengetahuan (Sowars, 2000: 3-10). Oleh karena itu, proses belajar harus melibatkan semua aspek kepribadian manusia, yaitu mulai dari aspek yang berhubungan dengan pikiran, perasaan, bahasa tubuh, pengetahuan, sikap, dan keyakinan. Menurut Magnesen dalam Dryden (2000:100) bahwa dalam belajar siswa akan memperoleh 10\% dari apa yang dibaca, 20\% dari apa yang didengar, 30\% dari apa yang dilihat, 50\% dari apa yang dilihat dan didengar, 70\% dari apa yang dikatakan dan 90\% dari apa yang dikatakan dan dilakukan.

Unsur kedua dari PAKEM adalah kreatif. Kreatif artinya memiliki daya cipta, memiliki kemampuan untuk berkreasi (Silberman, 2000:9). Peran aktif siswa dalam proses pembelajaran akan menghasilkan generasi yang kreatif, artinya generasi yang mampu menghasilkan sesuatu untuk kepentingan dirinya dan orang lain. Kreatif juga dimaksudkan agar guru menciptakan kegiatankegiatan belajar yang beragam sehingga memenuhi berbagai tingkat kemampuan siswa. Menurut Semiawan (1999:66) daya kreatif tumbuh dalam diri seseorang dan merupakan pengalaman yang paling mendalam dan unik bagi seseorang. Untuk menimbulkan daya kreatif tersebut diperlukan suasana yang kondusif yang menggambarkan kemungkinan tumbuhnya daya tersebut. Suasana kondusif yang dimaksud dalam PAKEM adalah suasana belajar yang memberi kesempatan siswa untuk terlibat secara aktif dan memberi kesempatan pada siswa untuk dapat mengemukakan gagasan dan ide tanpa takut disalahkan oleh guru.

Adapun pembelajaran yang efektif terwujud karena pembelajaran yang dilaksanakan dapat menumbuhkan daya kreatif bagi siswa sehingga dapat membekali siswa dengan berbagai kemampuan. Setelah proses pembelajaran berlangsung, kemampuan yang diperoleh siswa tidak hanya berupa pengetahuan yang bersifat verbalisme namun diharapkan berupa kemampuan yang lebih bermakna. Artinya, pembelajaran dapat mengembangkan berbagai potensi yang ada dalam diri siswa sehingga menghasilkan kemampuan yang beragam. Belajar yang efektif dapat dicapai dengan tindakan nyata (learning by doing) dikemas dengan berbagai metode yang dapat mengembangkan proses berpikir siswa. Belajar akan menjadi lebih bermakna jika yang dipelajari sesuai dengan kebutuhan pemelajar dipantau secara berkesinambungan. Untuk siswa SD kelas rendah dapat dikemas dengan bermain. Bermain dan bereksplorasi dapat membantu perkembangan otak, berbahasa, bernalar, dan bersosialisasi.

Menyenangkan adalah suasana pembelajaran yang dapat memusatkan perhatian siswa secara penuh pada belajar sehingga waktu curah perhatiannya tinggi. Menurut hasil penelitian tingginya perhatian siswa terbukti dapat meningkatkan hasil belajar. Keadaan aktif dan menyenangkan tidaklah cukup jika proses pembelajaran tidak efektif yang tidak menghasilkan apa yang harus dikuasai siswa selama proses pembelajaran berlangsung sebab pembelajaran memiliki sejumlah tujuan yang harus dicapai. Jika pembelajaran hanya aktif dan menyenangkan tetapi tidak efektif maka pembelajaran tersebut tidak ubahnya seperti bermain biasa. Kelas yang sunyi, siswa sebagai pendengar pasif, tidak ada aktivitas konkret, membosankan, belajar tidak efektif, tidak kritis, tidak kreatif, komunikasi buruk, dan apatis. Kondisi yang menyenangkan, aman, dan nyaman akan mengaktif-kan bagian neo-cortex (otak berpikir) dan mengoptimal-kan proses belajar dan meningkatkan kepercayaan diri siswa. Suasana kelas yang kaku, penuh beban, guru galak akan menurunkan fungsi otak menuju batang otak dan siswa tidak bisa berpikir efektif, reaktif atau agresif (Pancamegawani, 2006).

Berdasarkan uraian di atas, dapat dideskripsikan bahwa dalam PAKEM siswa terlibat dalam berbagai kegiatan pembelajaran yang dapat mengembangkan pemahaman dan kemampuan mereka melalui berbuat atau melakukan. Kemudian dalam PAKEM guru menggunakan berbagai alat bantu atau media dan berbagai metode. Dengan kata lain dapat dikatakan bahwa dalam PAKEM guru menggunakan multimedia dan berbagai metode sehingga kegiatan pembelajaran yang tercipta dapat membangkitkan semangat siswa dan dapat mengembangkan berbagai potensi yang ada dalam diri siswa. Hal yang tidak kalah pentingnya adalah PAKEM menggunakan lingkungan sebagai sumber belajar untuk menjadikan pembelajaran menarik, menyenangkan, dan cocok bagi siswa. Untuk 
Kemampuan Guru dalam...

penataan kelas dalam PAKEM, guru mengatur kelas dengan memajang buku-buku dan bahan belajar yang lebih menarik dan menyediakan pojok baca. Dengan demikian, siswa dapat memanfaatkan sumber belajar yang ada dalam kelas sehingga kemampuan siswa dapat berkembang lebih optimal.

Dalam strategi pembelajaran guru menerapkan cara membelajarkan yang lebih kooperatif dan interaktif termasuk cara belajar kelompok. Guru mendorong siswa untuk menemukan caranya sendiri dalam pemecahan suatu masalah, untuk mengungkapkan gagasannya dan melibatkan siswa dalam menciptakan lingkungan sekolahnya.

\section{Hal yang Harus Diketahui dan Diperhatikan Guru dalam Melaksanakan PAKEM}

Terdapat beberapa hal yang harus dipahami dan diperhatikan guru dalam melaksanakan PAKEM. Hal-hal tersebut adalah sebagai berikut (Pancamegawani, 2006).

\section{Memahami sifat yang dimiliki siswa}

Siswa memiliki berbagai potensi dalam dirinya. Di antaranya rasa ingin tahu dan berimajinasi. Dua hal ini adalah potensi yang harus dikembangkan atau distimulasi melalui kegiatan belajar membelajarkan. Kedua hal tersebut adalah modal dasar bagi berkembangnya sikap berpikir kritis dan kreatif. Sikap berpikir kritis dan kreatif adalah kompetensi yang harus dimiliki oleh siswa. Seperti dikemukakan oleh Jhonson (2002:24) salah satu komponen dalam sistem pembelajaran yang ideal adalah berpikir kritis dan kreatif. Artinya, siswa dapat menggunakan tingkat berpikir yang lebih tinggi. Kemampuan berpikir kritis dan kreatif serta sifat rasa ingin tahu dan berimajinasi yang sudah dimiliki siswa perlu dikembangkan. Untuk mengembangkan kedua sifat yang dimiliki siswa tersebut secara optimal perlu diciptakan suasana pembelajaran yang bermakna. Suasana pembelajaran bermakna ditunjukkan di antaranya dengan kebiasaan guru untuk memuji siswa karena hasil karyanya atau prestasinya. Kemajuan seperti apapun yang ditunjukkan oleh siswa perlu dihargai oleh guru.

2. Mengenal siswa secara perorangan

Para siswa berasal dari lingkungan keluarga yang bervariasi dan memiliki kemampuan yang berbeda. Dalam PAKEM perbedaan individual perlu diperhatikan dan harus tercermin dalam kegiatan pembelajaran. Semua siswa dalam kelas tidak selalu mengerjakan kegiatan yang sama, melainkan berbeda sesuai dengan kecepatan belajarnya. Siswa yang memiliki kemampuan lebih dapat dimanfaatkan untuk membantu temannya yang lemah (tutor sebaya). Dengan mengenal kemampuan siswa, guru dapat membantunya bila mendapat kesulitan sehingga siswa tersebut belajar secara optimal.

3. Memanfaatkan perilaku siswa dalam pengorganisasian belajar

Sebagai makhluk sosial, siswa sejak kecil secara alami bermain berpasangan atau berkelompok dalam bermain. Perilaku ini dapat dimanfaatkan dalam pengorganisasian belajar. Dalam melakukan tugas atau membahas sesuatu, siswa dapat bekerja, berpasangan atau dalam kelompok. Berdasarkan pengalaman, siswa akan menyelesaikan tugas dengan baik bila mereka duduk berkelompok. Duduk seperti ini memudahkan mereka untuk berinteraksi dan bertukar pikiran. Namun demikian, siswa perlu juga menyelesaikan tugas secara perorangan agar bakat individunya berkembang.

4. Mengembangkan kemampuan berpikir kritis, kreatif, dan kemampuan memecahkan masalah

Pada dasarnya hidup ini adalah memecahkan masalah. Hal tersebut memerlukan kemampuan berpikir kritis dan kreatif. Kritis untuk menganalisis masalah dan kreatif untuk melahirkan alternatif pemecahan masalah. Kedua jenis berpikir tersebut, kritis dan kreatif, berasal dari rasa ingin tahu dan imajinasi yang keduanya ada pada diri anak sejak lahir. Oleh karena itu, tugas guru adalah mengembangkannya, antara lain dengan seringnya memberikan tugas atau mengajukan pertanyaan yang terbuka. Pertanyaan yang dimulai dengan kata-kata "Apa yang terjadi jika...., lebih baik daripada yang dimulai dengan kata-kata "Apa, Berapa, Kapan" yang umumnya tertutup hanya ada satu jawaban yang benar.

5. Mengembangkan ruang kelas sebagai lingkungan belajar yang menarik

Ruang kelas yang menarik merupakan hal yang sangat disarankan dalam PAKEM. Hasil pekerjaan siswa sebaiknya dipajangkan untuk memenuhi ruang kelas seperti itu. Selain itu, hasil pekerjaan yang dipajangkan diharapkan memotivasi siswa untuk bekerja lebih baik dan menimbulkan inspirasi bagi siswa lain. Barang yang dipajangkan dapat berupa hasil kerja perorangan, berpasangan, atau kelompok. Pajangan dapat berupa gambar, peta, diagram, model, benda asli, puisi, dan karangan. Ruang kelas yang penuh dengan pajangan hasil pekerjaan siswa, dan ditata dengan baik dapat membantu guru dalam KBM karena dapat dijadikan rujukan ketika membahas suatu masalah.

6. Memanfaatkan lingkungan sebagai sumber belajar Lingkungan (fisik, sosial atau budaya) merupakan sumber yang sangat kaya untuk bahan belajar siswa. Lingkungan dapat berperan sebagai 
media belajar, tetapi juga sebagai objek kajian (sumber belajar). Penggunaan lingkungan sebagai sumber belajar sering membuat siswa merasa senang dalam belajar. Belajar dengan menggunakan lingkungan tidak harus selalu keluar kelas. Bahan dari lingkungan dapat dibawa ke ruang kelas untuk menghemat biaya dan waktu. Pemanfaatan lingkungan dapat mengembangkan sejumlah keterampilan seperti mengamati (dengan seluruh indra), mencatat, merumuskan pertanyaan, berhipotesis, mengklasifikasikan, membuat tulisan, dan membuat gambar atau diagram.

7. Memberikan umpan balik yang baik untuk meningkatkan kegiatan belajar

Mutu hasil belajar akan meningkat bila terjadi interaksi dalam belajar. Pemberian umpan balik dari guru kepada siswa merupakan salah satu bentuk interaksi antara guru dan siswa. Umpan balik hendaknya lebih mengungkap kekuatan daripada kelemahan siswa. Selain itu, cara memberikan umpan balik pun harus secara santun. Hal ini dimaksudkan agar siswa lebih percaya diri dalam menghadapi tugas-tugas belajar selanjutnya. Guru harus konsisten memeriksa hasil pekerjaan siswa dan memberikan komentar dan catatan. Catatan guru berkaitan dengan pekerjaan siswa lebih bermakna bagi pengembangan diri siswa dari hanya sekedar nilai (skor).

8. Membedakan antara aktif fisik dan aktif mental

Banyak guru yang sudah merasa puas bila menyaksikan para siswa kelihatan sibuk bekerja dan bergerak. Apalagi jika bangku dan meja diatur berkelompok serta siswa duduk saling berhadapan. Keadaan tersebut bukanlah ciri yang sebenarnya dari PAKEM. Aktif mental lebih diinginkan daripada aktif fisik. Sering bertanya, mempertanyakan gagasan orang lain, dan mengungkapkan gagasan merupakan tanda-tanda aktif mental. Pemberian soal-soal yang menantang akan dapat mengaktifkan mental siswa, soal-soal terbuka (open ended) harus lebih banyak diberikan agar siswa aktif bekerja. Berkembangnya aktif mental adalah tumbuhnya perasaan tidak takut baik takut ditertawakan, takut disepelekan atau takut dimarahi jika salah.

\section{Implementasi PAKEM dalam Kegiatan Pem- belajaran di SD}

Gambaran pelaksanaan PAKEM diperlihatkan dengan berbagai kegiatan yang terjadi selama KBM. Berdasarkan kemampuan yang harus dimiliki guru dalam melaksanakan PAKEM yang telah diuraikan di atas maka kegiatan pembelajaran yang dilaksanakan guru harus sesuai dengan kemampuan tersebut. Adapun contoh-contoh kegiatan pembelajaran yang sesuai dengan kemampuan tersebut akan diuraikan berikut ini. Gambaran penerapan PAKEM tersebut dapat ditinjau berdasarkan beberapa komponen pembelajaran.

\section{Kegiatan belajar membelajarkan}

Guru merancang dan mengelola KBM yang mendorong siswa untuk berperan aktif dalam pembelajaran. Adapun hal baru yang berbeda dengan kebiasaan pembelajaran selama ini adalah guru melaksanakan KBM dalam kegiatan yang beragam, misalnya percobaan, diskusi kelompok menulis laporan, dan berkunjung ke luar kelas.

2. Alat bantu dan sumber belajar

Guru menggunakan alat bantu dan sumber belajar yang beragam. Sesuai mata pelajaran, guru menggunakan, misalnya alat yang tersedia atau yang dibuat sendiri, gambar, studi kasus, narasumber, dan lingkungan.

3. Metode pembelajaran

Guru memberi kesempatan kepada siswa untuk mengembangkan keterampilan. Siswa dapat melakukan percobaan, pengamatan atau wawancara. Mengumpulkan data/jawaban dan mengolahnya sendiri, menarik kesimpulan, memecahkan masalah, mencari rumus sendiri, menulis laporan/hasil karya lain dengan kata-kata sendiri.

4. Pengalaman belajar

Guru memberi kesempatan kepada siswa untuk mengungkapkan gagasannya sendiri secara lisan atau tulisan. Melalui diskusi, lebih banyak pertanyaan terbuka, hasil karya merupakan pemikiran siswa sendiri.

5. Pemilihan bahan ajar

Guru menyesuaikan bahan dan kegiatan belajar dengan kemampuan siswa. Siswa dikelompokkan sesuai kemampuan (untuk kegiatan tertentu), bahan pelajaran disesuaikan dengan kemampuan kelompok tersebut, tugas perbaikan atau pengayaan diberikan. 6. Pendekatan pembelajaran kontekstual

Prinsip pembelajaran yang dilaksanakan adalah pembelajaran bermakna (meaningful learning). Salah satu ciri pembelajaran bermakna adalah pembelajaran yang kontekstual. Pembelajaran dirasakan terkait dengan kehidupan nyata dan siswa memahami manfaat dari pembelajaran yang dilaksanakannya dan siswa merasakan penting untuk belajar demi kehidupannya di masa depan (Kratf, 2000: 33). Implementasi dalam kegiatan pembelajaran terlihat melalui guru mengaitkan KBM dengan pengalaman siswa sehari-hari.

7. Penilaian atau evaluasi

Menilai KBM dan kemajuan belajar siswa secara terus menerus. Guru memantau kerja siswa dan guru memberikan umpan balik. Penilaian harus dilakukan 
secara autentik dengan menggunakan instrumen penilaian yang bervariasi (Kratf, 2000: 33).

\section{Kerangka Berpikir}

Berkaitan dengan pembelajaran PAKEM, halhal yang harus diperhatikan guru dalam perencanaan dan pelaksanaan pembelajaran adalah bahwa siswa memiliki berbagai potensi dalam dirinya, di antaranya rasa ingin tahu dan berimajinasi. Kedua hal ini adalah potensi yang harus dikembangkan atau distimulasi melalui kegiatan belajar membelajarkan karena hal tersebut adalah modal dasar bagi berkembangnya sikap berpikir kritis dan kreatif. Oleh karena itu, pembelajaran yang dilaksanakan guru haruslah menjadikan siswa aktif, interaktif, kreatif, efektif, dan menyenangkan.

Untuk menciptakan pembelajaran seperti tersebut maka diperlukan ruang kelas yang menarik. Hasil pekerjaan siswa sebaiknya dipajangkan untuk memenuhi ruang kelas seperti yang diharapkan. Selain itu, hasil pekerjaan yang dipajangkan diharapkan memotivasi siswa untuk bekerja lebih baik dan menimbulkan inspirasi bagi siswa lain. Benda yang dipajangkan dapat berupa hasil kerja perorangan, berpasangan atau kelompok. Pajangan dapat berupa benda asli, gambar, peta, diagram, model, puisi, dan karangan. Ruang kelas yang penuh dengan pajangan hasil pekerjaan siswa, dan ditata dengan baik dapat membantu guru dalam melaksanakan pembelajaran.

Berkaitan dengan hal tersebut, perlu adanya upaya yang berkelanjutan melalui berbagai cara, misalnya dengan meningkatkan kualifikasi melalui pendidikan prajabatan dan mengikuti pelatihanpelatihan. Guru juga dituntut untuk memiliki motivasi agar selalu berupaya untuk mengembangkan diri menjadi guru yang profesional, inovatif, dan kreatif.

\section{METODOLOGI PENELITIAN}

Penelitian bertujuan untuk mendeskripsikan dan kemudian menganalisis kemampuan guru dalam melaksanakan PAKEM di SD. Penelitian ini akan dilakukan di SD di dua provinsi, yaitu Provinsi Bali dan Jawa Tengah. Masing-masing provinsi diwakili dua SD sebagai subjek dalam penelitian ini. Penelitian dilaksanakan pada bulan Februari sampai dengan Oktober 2007. Variabel penelitian ini adalah kemampuan guru dalam melaksanakan pembelajaran yang menerapkan PAKEM.

Sesuai dengan tujuan yang hendak dicapai, metode penelitian yang digunakan adalah penelitian kualitatif yang dilakukan dalam latar alamiah tanpa intervensi dari peneliti. Peneliti merupakan instrumen untuk mengumpulkan data dan menganalisisnya secara induktif, dengan memberikan gambaran yang jelas dan akurat tentang material atau fenomena yang sedang diamati.

Penelitian kualitatif menurut Denzin dan Lincoln (1994:2) adalah berfokus pada metode jamak (multimethod) meliputi pendekatan interpretif naturalistik atas subjek yang diteliti. Penelitian ini menggunakan latar apa adanya dan berusaha memberi arti atau menafsirkan gejala yang dialami oleh mereka yang terlibat. Sementara itu, Creswell (1998:15) berpendapat bahwa penelitian kualitatif merupakan suatu proses penelitian yang didasarkan pada metodologi tersendiri untuk mengungkap masalah sosial atau manusia.

Bentuk penelitian kualitatif menurut pendapat Moleong (1991:27) berakar pada latar alamiah sebagai keutuhan, mengandalkan manusia sebagai alat penelitian, dan menganalisis data secara induktif. Ciri khas penelitian kualitatif adalah: (1) memperlakukan latar alamiah sebagai sumber data, dan peneliti sebagai instrumen utama; (2) sifatnya deskriptif, yaitu bahwa data yang dikumpulkan berupa kata-kata dan gambar, dan bukan angka; (3) lebih mementingkan proses daripada hasil; (4) cenderung menganalisis data secara induktif; dan (5) pemberian makna atas data merupakan perhatian utama (Bogdan dan Biklen, 1982:68-70). Dalam penelitian kualitatif tidak dipersoalkan jumlah subjek yang diteliti karena tidak untuk keperluan generalisasi. Objek penelitian ini adalah prakarsa sekolah dalam mengembangkan PAKEM yang merupakan pengalaman dari sejumlah guru mengenai PAKEM. Oleh karena penelitian ini mengkaji suatu gejala maka termasuk dalam kategori penelitian fenomenologis. Penelitian fenomenologis menurut Kockelmans (1967:22-23) bermuara pada pandangan filsafat Husserl yang menganggap bahwa pengetahuan merupakan sesuatu yang tampak dalam kesadaran.

Sumber data adalah sekolah yang telah dipilih dengan pertimbangan pragmatik. Pengumpulan data dilakukan dengan observasi dalam kelas, wawancara, dan analisis dokumen. Observasi kegiatan pem-belajaran di kelas dengan menggunakan format lembar observasi. Observasi pelaksanaan pembelajaran di kelas dilaksanakan minimal selama satu jam pembelajaran yang mencakup tiga kegiatan yaitu pendahuluan, kegiatan inti, dan penutup. Untuk menguatkan hasil observasi tersebut, peneliti mewawancarai guru kelas yang diamati dan pimpinan sekolah. Wawancara untuk guru dan pimpinan 
sekolah menggunakan pedoman wawancara.

Analisis data kualitatif adalah analisis deskriptif yang dapat menjawab pertanyaan-pertanyaan dasar dan memastikan bahwa semua data yang dibutuhkan sudah lengkap serta kualitasnya sudah diperiksa terlebih dahulu. Dalam pengkajian, triangulasi dilakukan dengan membandingkan data hasil observasi, hasil wawancara, dan data dokumen-tasi. Prosedur analisis tersebut melalui reduksi data, penyajian data, dan kesimpulan serta verifikasi. Dalam penelitian kualitatif, keabsahan data dilakukan secara berbeda dengan penelitian kuantitatif. Dalam penelitian ini, pemeriksaan keabsahan data dilakukan dengan lima cara, yaitu dengan perpanjangan waktu, triangulasi, review sejawat, menyempurnakan pedoman kerja selama berlangsungnya penelitian, dikoreksi dan diperbaiki sesuai dengan kenyataan lapangan yang sesungguhnya agar lebih realistik, serta klarifikasi ketidakberpihakan peneliti untuk menjaga netralitas peneliti.

\section{HASIL PENELITIAN}

Pada beberapa sekolah yang menjadi subjek dalam penelitian ini ditemukan hasil penelitian dan pembahasan sebagai berikut.

1. SDN No. 2 Sesetan Denpasar Bali

a. Observasi kelas

\section{1) Observasi mata pelajaran IPA}

Pengamatan pembelajaran dilaksanakan di kelas IV. Kompetensi yang ingin dicapai adalah memahami bunyi dan sumber bunyi. Kegiatan pembelajaran diawali dengan ceramah dan diselingi dengan tanya jawab. Kemudian salah seorang siswa ditunjuk untuk mendemonstrasikan alat yang menghasilkan bunyi. Siswa diminta menyalin materi yang telah ditulis oleh guru di papan tulis. Dalam kegiatan pembelajaran tidak ada pembagian kelompok dan pembelajaran diakhiri dengan pemberian tes lisan.

Terakhir siswa mengumpulkan hasil tesnya untuk dinilai oleh guru. Sebelum pembelajaran berakhir guru mengajak siswa bernyanyi (tidak sesuai tema pembelajaran) dan berdoa. Mulai dari awal sampai akhir kegiatan pembelajaran didominasi oleh guru (teacher centered).

Hal yang sama juga terjadi pada pengamatan di kelas V. Dengan materi tentang
"Pembiasan Cahaya" kegiatan pembelajaran juga didominasi oleh guru dengan metode ceramah dan tanya jawab. Percobaan yang semestinya dibuktikan dengan alat peraga (media) hanya digambar oleh guru. Satu percobaan didemonstrasikan oleh guru tetapi tidak diberi kesempatan pada siswa untuk mencobanya.

Kondisi ruangan kelas IV seperti kelas pada umumnya, kelas ini terlihat sangat padat dengan jumlah siswa 41 orang. Kondisi kelas belum secara optimal menerapkan PAKEM. Kursi siswa disusun berbaris secara klasikal dengan jumlah kursi dan meja yang cukup banyak, yaitu 40 meja dan kursi sehingga kurang leluasa dipindahkan untuk kerja kelompok. Pada dinding kelas ada beberapa gambar pahlawan dan tidak terdapat hasil karya siswa. Pojok-pojok kelas juga tidak dimanfaatkan untuk aktivitas pembelajaran. Di pojok kelas terdapat sebuah lemari dan pohon ilmu yang tidak ada isinya.

2) Observasi mata pelajaran Matematika

Pengamatan dilakukan di kelas III. Materi yang dipelajari adalah tentang segitiga sama sisi. Sebelumnya guru memberikan apersepsi tentang perkalian secara mencongak. Guru tidak mengaitkan dengan lingkungan kelas. Kegiatan pembelajaran dilakukan dengan menerapkan metode ceramah kemudian memberi contoh soal lalu siswa ditugaskan menyelesaikannya di buku masing-masing. Siswa yang lain mengerjakan secara bergiliran di papan tulis. Ketika siswa mengerjakan latihan guru berkeliling mengamati siswa.

Pembelajaran yang dilaksanakan belum tematik. Suara guru kurang keras. Perintah di buku matematika adalah gambarkan bangun segitiga sama sisi jika diketahui kelilingnya, $9 \mathrm{~cm}, 12 \mathrm{~cm}, 15 \mathrm{~cm}, 18 \mathrm{dm}$, dan $21 \mathrm{dm}$. Siswa menggambar kelima segitiga sama sisi tersebut dengan ukuran yang sama dengan tidak menggunakan busur derajat atau jangka. Siswa tidak dapat membedakan ukuran panjang dengan satuan $\mathrm{cm}$ dan $\mathrm{dm}$. Pada akhir pembelajaran guru tidak memberi kesempatan siswa untuk refleksi diri dan tidak memberikan tindak lanjut dikaitkan dengan kehidupan sehari-hari.

Kondisi ruang kelas III lebih lengkap dibandingkan dengan kelas IV dan V. Dinding kelas berisi gambar pahlawan dan tidak ada 
pemajangan hasil karya siswa kecuali dua hasil lukisan siswa. Di pojok kelas terdapat pohon ilmu yang digunakan untuk meletakkan pekerjaan siswa dan guru menggunakannya sebagai tempat untuk meletakkan materimateri pokok (rumus-rumus dan soal-soal). Tidak adanya pemanfaatan pojok kelas untuk aktivitas belajar.

Kursi sulit untuk dipindahkan karena jumlahnya yang terlalu banyak dan sebagian besar kursi masih berupa bangku panjang. Oleh karena itu, guru tidak membagi siswa ke dalam kelompok-kelompok. Media dan alat peraga yang tersedia di kelas adalah gambar pahlawan (lima buah), huruf-huruf kapital dan huruf sambung, huruf-huruf bahasa Bali, dan media jam mainan dari $\mathrm{CD}$ bekas. Jumlah siswa terlalu banyak, yakni 51 orang (21 orang laki-laki dan 30 orang perempuan).

b. Observasi sekolah

Berdasarkan hasil pengamatan yang dilakukan, diketahui tidak terdapat buletin atau karya siswa. Sekolah ini sudah memiliki ruangan perpustakaan sendiri. Oleh karena perpustakaan ini baru selesai dibangun sehingga masih dalam proses penataan termasuk pendataan bukubukunya. Belum ada petugas perpustakaan, guru yang sedang tidak membelajarkan membantu bertugas mengelola perpustakaan. Sekolah ini sudah memiliki beberapa koleksi media dan alat peraga seperti televisi, Over Head Projector (OHP), dan komputer tetapi belum dimanfaatkan secara optimal sebagai media pembelajaran. Komputer baru ada satu buah diletakkan di ruang Tata Usaha (TU) dan televisi diletakkan di ruang guru.

Di depan perpustakaan terdapat satu bangunan yang dinamakan ruangan workshop. Bangunan ini terdiri atas empat ruangan. Satu ruangan digunakan sebagai tempat praktik Pendidikan Teknologi Dasar (PTD), satu ruangan direncanakan untuk ruangan komputer. Akan tetapi, saat ini ruang komputer masih kosong dan baru direncanakan sekolah ini akan mendapat bantuan sepuluh komputer dari pemerintah daerah. Internet sama sekali belum ada. Satu ruang dimanfaatkan untuk ruang pertemuan, dan satu ruang lagi untuk ruang guru PTD.

Di samping itu, sekolah ini juga memiliki satu ruang koperasi tetapi ruang laboratorium belum tersedia. Halaman sekolah dapat dimanfaatkan untuk olahraga, misalnya basket. Terdapat pula tempat beribadah yang dinamakan Pura Kesuma Bhuwana. c. Analisis dokumen

Perencanaan yang digunakan oleh guru baik silabus maupun Rencana Pelaksanaan Pembelajaran (RPP) bukan merupakan buatan guru sendiri, melainkan hasil kerja kelompok disusun oleh Tim Pengembang Silabus SD Provinsi Bali (dengan ketua Tim: Ketut Sudiana).

Pada guru kelas III, program semester baru ada program untuk semester satu, jadwal juga untuk semester satu. Materi hanya judul materi pokok. Tidak memuat strategi pembelajaran individu, juga tidak ada alokasi waktu. Penilaian minat dan sikap tidak ada. Guru tidak dapat menunjukkan RPP, adapun lembar siswa diambil dari buku. Assesment tidak direncanakan dan tidak ada perencanaan pemberian remedial dan pengayaan. Pada guru kelas IV, program semester dan jadwal semester dalam proses pembuatan. Silabus menggunakan hasil kerja kelompok, strategi pembelajaran tidak tergambar apakah kegiatan dilaksanakan secara klasikal, individual maupun kelompok. RPP bukan buatan guru sendiri, tidak ada lembar siswa, assesment tidak direncanakan dan tidak ada tindak lanjut. Pada guru kelas V, silabus mata pelajaran sains juga menggunakan silabus yang diterbitkan oleh Dinas Pendidikan Provinsi Bali. Pokok bahasan pada program semester berisi Standar Kompetensi (SK), Kompetensi Dasar (KD), hasil belajar, dan indikator. RPP bukan buatan guru sendiri, tidak ada lembar siswa, assesment tidak direncanakan serta terdapat tindak lanjut.

\section{d. Profil guru}

Jumlah guru diSD Negeri Sesetan 2 Denpasar Bali sebanyak 30 orang yang terdiri atas 12 orang guru laki-laki dan 18 orang guru perempuan. Dua di antaranya masih berstatus CPNS. Adapun kualifikasi gurunya sebanyak 15 orang sarjana, 11 orang D2, dan empat orang lulusan SLTA (SPG dua orang, SMA satu orang, dan SGO satu orang). 24 gurunya sudah golongan IV/a, satu orang golongan III/d, satu orang golongan III/c, satu orang golongan III/a, satu orang golongan II/b, dan dua orang golongan II/a.

e. Kesimpulan

Berdasarkan hasil observasi kelas yang dilakukan, yaitu di kelas III, IV, dan V diketahui pembelajaran yang dilaksanakan belum mencerminkan penerapan PAKEM, baik dari segi kegiatan pembelajarannya maupun dari segi setting kelas. Dengan jumlah siswa yang terlalu banyak di setiap kelas, yaitu sekitar 40-50 orang anak, pembelajaran yang dilaksanakan masih cenderung 
klasikal dan berpusat pada guru. Tidak ada pemanfaatan lingkungan sebagai sumber belajar, tidak ada pemajangan karya siswa, dan metode pembelajaran yang digunakan tidak bervariasi.

Berdasarkan penggabungan hasil observasi kelas dan analisis dokumen dapat disimpulkan bahwa kategori penguasaan guru, yaitu sedikit penguasaan dan pelaksanaan belum dilakukan secara optimal. Hasil ini didukung wawancara yang dilakukan dengan kepala sekolah diketahui bahwa berbagai kegiatan sudah dilakukan untuk meningkatkan kemampuan guru dalam pembelajaran di antaranya mengikutsertakan guru dalam pelatihan-pelatihan di tingkat kabupaten seperti materi Kurikulum Tingkat Satuan Pendidikan (KTSP) dan mengadakan kerja sama dengan Lembaga Pendidik Tenaga Kependidikan (PGSD). Upaya peningkatan kemampuan guru ini mendapat dukungan dari pengawas dan komite. Hubungan sekolah dengan komite sangat baik sehingga bantuan dana dari komite berjalan dengan lancar. Namun, berbagai upaya yang dilakukan sekolah masih terdapat beberapa kendala terutama kendala SDM, dana, dan fasilitas yang masih terbatas.

Hasil penelitian ini memberi gambaran bahwa peningkatan kemampuan guru masih perlu dilakukan terutama dalam hal pelaksanaan kegiatan belajar membelajarkan. Paradigma guru tentang pembelajaran betul-betul perlu diubah. Guru harus memahami bahwa penguasaan akademik atau pengetahuan secara verbalisme bukan menjadi tujuan utama dalam pembelajaran. Guru perlu mengupayakan bagaimana mengoptimalkan keaktifan siswa dalam pembelajaran dan merancang pembelajaran yang betul-betul bermakna bagi siswa. Kegiatan pembelajaran dapat mengembangkan potensi siswa secara optimal sehingga apa yang dipelajari di sekolah dapat diimplementasikan secara kontekstual dalam kehidupan sehari-hari.

Akan tetapi, untuk mewujudkan itu semua satu hal yang juga harus menjadi perhatian atau pemikiran yaitu jumlah siswa yang terlalu banyak di setiap kelas dengan perbandingan 1:40 atau 1:50 cukup menjadi kendala guru dalam melaksanakan pembelajaran sesuai dengan PAKEM. Di samping itu, peningkatan kesejahteraan guru terutama di daerah juga satu hal yang menjadi syarat untuk mewujudkan pembelajaran yang sesuai dengan harapan.

2. SDPN Tulangampiang Denpasar Bali

a. Observasi kelas

1) Observasi mata pelajaran Matematika

Pengamatan pembelajaran dilaksanakan

di kelas V SDPN Tulangampiang Denpasar Bali. SK yang ingin dicapai adalah memahami skala dan perbandingan. Pada pendahuluan guru memberikan apersepsi dan menyatakan tema pembelajaran hari itu namun tidak menyatakan tujuan yang ingin dicapai serta tidak mengaitkan dengan lingkungan.

Kegiatan inti dilaksanakan dengan guru membagi siswa menjadi sembilan kelompok, dengan cara siswa membilang berurutan mulai dari satu sampai sembilan kemudian yang bernomor sama mencari temannya. Ketika pembagian kelompok, suasana kelas menjadi gaduh. Masing-masing kelompok membahas topik yang sama, yang ada di buku matematika halaman 121 nomor enam dan tujuh. Buku yang dipakai memenuhi standar SK Dirjen Dikdasmen nomor 455/C/KEP/LK/ 2004.

Masing-masing kelompok mengumpulkan pekerjaan pada guru (tidak dipresentasikan). Setelah itu, guru memberi tanggapan dengan cara menanyakan soal yang belum bisa dikerjakan dan siswa menjawabnya. Kegiatan pembelajaran terlalu lama pada kegiatan kelompok, sekitar 70 menit guru memberikan waktu untuk kerja kelompok. Guru tidak mengadakan kegiatan penutup sesuai dengan kompetensi yang ingin dicapai tetapi langsung berganti pokok bahasan, yaitu tentang geometri dan pengukuran, khususnya pengukuran luas dan keliling trapesium.

Kelas V SDPN Tulangampiang menempati ruang multimedia sekaligus tempat penyimpanan alat laboratorium IPA. Dinding kelas kosong dan tidak terdapat pajangan. Kursi siswa dapat dipindahkan karena siswa masingmasing menggunakan kursi yang sekaligus ada mejanya (seperti kursi kuliah). Oleh karena menggunakan ruang kelas sekaligus ruang multimedia maka sudut kelas ada KIT IPA dan rangka manusia, di dalam kelas juga terdapat TV 35" dan komputer namun ketika itu tidak digunakan. Jumlah siswa yang masuk 38 orang dari 40 siswa. Ruang ber- $A C$, tetapi ketika itu tidak dihidupkan.

2) Observasi mata pelajaran IPA

Pengamatan pembelajaran dilaksanakan di kelas IV SDPN Tulangampiang Denpasar Bali. Kegiatan pembelajaran merupakan pemantapan/penerapan dari pertemuan sebelumnya sehingga semua kegiatan pendahuluan tidak ada. Guru memberikan lembar tugas individual, yaitu siswa ditugaskan membuat alat musik dengan bahan yang sudah disiapkan siswa.

Guru tidak memberi kesempatan secara 
kelompok, misalnya siswa yang membuat alat musik sejenis mencobakan alatnya secara bersama-sama. Guru secara individual memberi penguatan dan tanggapan. Metode pembelajaran guru kurang bervariasi. Siswa membuat alat musik dari bahan sederhana, yang berasal dari lingkungan, misalnya kaleng bekas, tutup botol, dan kertas bekas untuk membuat terompet.

Pada kegiatan penutup, guru tidak merangkum pelajaran namun mengadakan evaluasi proses, selanjutnya memberikan umpan balik tetapi tidak memberi kesempatan siswa untuk merefleksi diri dan tidak memberikan tindak lanjut dikaitkan dengan kehidupan sehari-hari. Kegiatan akhir diisi dengan penilaian pekerjaan rumah.

Dinding kelas berisi papan data kelas, sebuah peta pulau Bali, dua gambar pahlawan, dan dua karya siswa yang dijadikan sebagai hiasan. Kursi siswa kurang leluasa karena jumlah meja dan bangku yang terlalu banyak. Sudut kelas tidak ada yang dimanfaatkan untuk aktivitas belajar dan pembelajaran. Jumlah siswa dalam satu kelas 39 orang.

b. Observasi sekolah

Dinding sekolah terdapat tempelan hasil karya siswa. Perpustakaan sekolah mempunyai ruangan khusus dengan ukuran $7 \times 7 \mathrm{~m}^{2}$, dengan dua orang petugas honorer. Terdapat komputer dan sebuah komputer game, juga terdapat dua meja besar dan kursi-kursi sebagai tempat baca. Kunjungan setiap hari 30 orang, dengan jumlah peminjaman setiap bulan 0,51\% siswa. Jumlah koleksi terdiri dari buku fiksi 999 eksemplar dan nonfiksi 4017 eksemplar.

Koleksi media dan alat peraga lain, di antaranya adalah TV/CD/VCD empat buah, $\mathrm{OHP}$ satu buah, $L C D$ projector satu buah, komputer enam buah, dan $C D$ program pembelajaran beberapa set, antara lain seri pembelajaran matematika mandiri untuk tingkat $S D, C D$ bahasa Inggris, $C D$ Matematika 19 buah dan IPA 15 buah. Laboratorium yang ada adalah ruang multimedia sekaligus berperan sebagai ruang kelas $\mathrm{V}$, dan ruang laboratorium IPA. Terdapat ruang serbaguna, ada bale bengong digunakan untuk pentas seni dan bale bandung yang berisi perpustakaan/buku-buku tentang kebudayaan Bali. Ruang guru luasnya $7 \times 8 \mathrm{~m}^{2}$. Sarana yang ada antara lain TV 29", meja kursi guru, lemari, dan locker. Ruang kepala sekolah luasnya 7 × $3 \mathrm{~m}^{2}$. dan Ruang TU 3,7 × 3,4 $\mathrm{m}^{2}$. Internet di SDPN Tulangampiang belum ada. Guru yang menguasai komputer kurang dari 50\% walaupun sudah diikutsertakan kursus komputer, hal ini disebabkan guru-guru perempuan khawatir merusak komputer tersebut .

c. Analisis dokumen

Analisis dokumen diwakili oleh dua mata pelajaran berikut.

1) Mata pelajaran Matematika

Pada program semester, yang diberikan pada peneliti adalah program semester yang digunakan pada semester satu dan dua tahun ajaran 2005/2006. Alasannya program semester yang baru masih dalam rangka pembuatan. Silabus tidak mencantumkan strategi pembelajarannya, apakah klasikal, kelompok maupun individu. Silabus juga tidak mencantumkan penilaian minat, sikap, dan aktivitas. Guru kelas V yang merupakan guru bidang studi Matematika ketika itu tidak dapat memperlihatkan RPP dengan pokok bahasan skala dan perbandingan tetapi yang diberikan adalah RPP tentang luas dan keliling trapesium, pelaksanaan kegiatan pembelajarannya di akhir pertemuan (setelah kegiatan berlangsung 70 menit). Terlihat pula bahwa guru baru melengkapi pembuatan RPP di kelas ketika siswa mengadakan diskusi kelompok.

Selain itu, guru kelas V SDPN Tulangampiang Denpasar menggunakan program semester satu dan dua secara bersamasama (yang diperjualbelikan di toko buku) namun hanya terisi sebagian. Jadwal pelajarannya pun masih jadwal untuk tahun ajaran 2005/2006.

2) Mata pelajaran Bahasa Indonesia

Pada program semester, yang digunakan masih tahun ajaran 2004/2005. Silabus bukan karya sendiri dan tidak terdapat jadwal semester. Silabus juga tidak dilengkapi dengan alokasi waktu. Terdapat penilaian sikap dan aktivitas tetapi tidak ada penilaian minat. RPP tidak ada kegiatan pembukaan, tidak ada Lembar Kerja Siswa (LKS), kriteria assesment, dan tidak dilengkapi dengan tindak lanjut.

\section{d. Profil guru}

Guru tetap berjumlah 21 orang, sepuluh orang berkualifikasi sarjana (S1), 11 orang berkualifikasi D2. Tiga orang pegawai administrasi merupakan PNS, dengan kualifikasi seorang lulusan SMEA dan dua orang KPAA. Adapun guru tidak tetap berjumlah sembilan orang dengan 
kualifikasi sarjana tujuh orang dan SPG atau sederajat dua orang.

e. Kesimpulan

Hasil wawancara dengan kepala sekolah ditemukan bahwa sekolah sudah berusaha untuk mengikutsertakan guru dalam pembuatan silabus, menyusun RPP tetapi guru malas untuk menyusun sendiri silabus dan RPP karena terdapat produk instan yang diperjualbelikan. Guru juga belum optimal dalam kemelekwacanaan tentang komputer walaupun sudah dikursuskan, dengan alasan takut rusak. Hasil ini juga menjadi masukan bagi komite sekolah agar tidak hanya menitikberatkan pada pembangunan fisik sekolah tetapi juga mulai memperhatikan perangkatperangkat proses pembelajaran.

Berdasarkan hasil observasi kelas, kelemahan guru pada kegiatan penutup, yakni tidak memberi kesempatan siswa untuk mengadakan refleksi diri. Adapun berdasarkan analisis dokumen guru perlu meningkatkan diri dalam penyusunan silabus, penyusunan RPP, pembuatan LKS dan menentukan strategi pembelajaran, serta merencanakan kegiatan perbaikan dan pengayaan.

3. SDN Sedayu 1 Muntilan Jawa Tengah

a. Observasi kelas

1) Observasi mata pelajaran Bahasa Indonesia Pengamatan pembelajaran dilaksanakan di kelas V SDN Sedayu 1 Muntilan Jateng. Standar kompetensi yang ingin dicapai adalah siswa dapat mendeskripsikan toko swalayan. Pada pendahuluan guru memberikan apersepsi, menyatakan tema pembelajaran hari itu, dan tujuan yang ingin dicapai. Selain itu, mengaitkan dengan lingkungan dengan membandingkan antara warung kelontong dan toko swalayan yang ada di Muntilan.

Kegiatan inti dilaksanakan dengan guru membagi menjadi 16 kelompok, masing-masing kelompok mencari kata-kata sulit dalam bacaan (sampai tiga bacaan atau tiga lembar, diberikan tiga kali). Setelah selesai masing-masing kelompok mempresentasikan hasil diskusi.

Guru memberi penguatan setelah selesai presentasi kelompok kemudian diberi applaus. Guru tidak menggunakan lingkungan (sarana) dalam kelas untuk pembelajaran. Guru merangkum bersama siswa. Guru mengadakan evaluasi secara individu, tidak memberikan umpan balik, dan refleksi diri. Guru juga tidak memberikan tindak lanjut dikaitkan dengan kehidupan sehari-hari.
Dinding kelas banyak dipenuhi pajangan hasil karya siswa, ada yang dimasukkan mapmap transparan yang ditempel di dinding. Juga terdapat jam-jaman dari $C D$ bekas yang menandakan jam berapa siswa sampai di kelas. Kursi dapat dipindahkan untuk setting diskusi. Sudut kelas terdapat buku pelajaran kelas V, perpustakaan kelas, dan gambar wayang kulit. Media dan alat peraga yang terdapat di dalam kelas, antara lain wayang kulit, buku-buku, gambar cara mencegah cacingan dan diare, jam mainan dari $C D$ bekas, gambar empat sehat lima sempurna. Jumlah siswa dalam satu kelas 48 orang. Ini merupakan penggabungan kelas VA dan V B karena guru kelas V sedang mengikuti pelatihan bidang studi di Semarang. Biasanya jumlah siswa kelas $\mathrm{V}$ dalam satu kelas hanya 24 orang.

2) Observasi mata pelajaran IPA

Pengamatan pembelajaran dilaksanakan di kelas IV SDN Sedayu 1 Muntilan Jateng. Standar kompetensi yang ingin dicapai adalah memahami berbagai bentuk dan cara penggunaan energi alternatif. Pada pen-dahuluan, guru memberikan apersepsi, menyatakan tema pembelajaran hari itu tetapi tidak menyatakan secara eksplisit tujuan yang ingin dicapai kemudian guru mengaitkan dengan lingkungan dengan memberi contoh kincir angin untuk pembangkit tenaga listrik. Kegiatan inti dilaksanakan dengan diskusi kelompok untuk membuat baling-baling dari kertas.

Guru membagikan kertas karton tanpa tulisan yang dapat dibuat baling-baling, tugas didiktekan. Setelah selesai beberapa kelompok mencoba baling-baling buatan mereka sambil berlari di luar kelas, jika baling-baling dapat memutar, bersoraklah mereka. Guru tidak memberikan tanggapan, kurang memberikan penguatan.

Penggunaan lingkungan (sarana) dalam kelas untuk pembelajaran selain kertas karton adalah bambu untuk membuat tangkai balingbaling. Penerapan PAKEM sudah terlihat namun belum optimal karena dalam kegiatan pembelajaran tidak semua siswa antusias dan aktif. Guru tidak merangkum pelajaran, tidak memberikan evaluasi secara tertulis, dan evaluasi dilakukan dalam proses serta hasil. Guru tidak memberikan umpan balik dan tidak memberikan kesempatan pada siswa untuk 
merefleksi diri. Guru memberi tindak lanjut dikaitkan dengan kehidupan sehari-hari.

Terdapat beberapa pajangan di dinding, ada beberapa gambar, rak buku, dan jam mainan dari $C D$ bekas. Siswa leluasa untuk berdiskusi karena setiap siswa satu kursi. Sudut kelas diisi lemari, meja, dan kursi guru. Media dan alat peraga yang tersedia di kelas hanya jam mainan dari $C D$ bekas serta papan tulis. Jumlah siswa dalam satu kelas 40 orang.

b. Observasi sekolah

Dinding sekolah terdapat karya siswa. Perpustakaan sekolah mempunyai ruangan khusus dengan ukuran $7 \times 7 \mathrm{~m}^{2}$ dan tidak ada ruang baca. Koleksi buku-buku terdiri dari buku fiksi 3.592 eksemplar dan nonfiksi 321 eksemplar. Menurut petugas perpustakaan lebih dari 2.000 buku tidak dicatat karena kondisi buku sudah rusak. Hal yang membahayakan di ruang perpustakaan juga terdapat kompor gas untuk memasak air minum.

Koleksi media dan alat peraga lain, di antaranya adalah radio tape dua buah dan komputer baru tiga buah. Sekolah tidak mempunyai $T V$, $O H P$, laptop, dan LCD. Laboratorium yang ada hanya laboratorium IPA dilengkapi dengan peralatan Science Education Quality Improvement Project (SEQIP), rangka tubuh manusia (untuk sementara laboratorium IPA juga digunakan untuk ruang sholat karena mushola sedang direnovasi). Sekolah belum mempunyai ruang kreatif kecuali pemanfaatan halaman sekolah yang sekaligus sebagai tempat olahraga dan upacara bendera. Teknologi informasi dan komunikasi belum tersentuh dan komputer untuk siswa belum ada. Kepala sekolah membentuk klinik pembelajaran dengan cara mengajak guru ke warnet milik pondok pesantren Pabelan untuk belajar komputer dan bagaimana cara menggunakan internet.

Ruang guru luasnya $5 \times 7 \mathrm{~m}^{2}$. Sarana yang ada antara lain radio compo, dispenser, tape desk, meja kursi guru, komputer dua buah, dan meja kursi tamu. Ruang kepala sekolah luasnya 3 × 7 $\mathrm{m}^{2}$, terbagi menjadi ruang tamu dan ruang kerja. Melihat sarana dan prasarana yang dimiliki sangat minim, serta gedung yang sudah tua, menggambarkan bahwa sekolah ini seperti SD inpres pada umumnya.

\section{c. Analisis dokumen}

Analisis dokumen diwakili oleh dua mata pelajaran berikut.

1) Mata pelajaran Bahasa Indonesia

Pada program semester terdapat jam pelajaran dan alokasi waktu serta mencantum- kan pokok bahasan. Jadwal semester memuat jumlah jam pelajaran dan pokok bahasan. Pada komponen silabus memuat penjabaran materi, tidak secara eksplisit disebutkan strategi pembelajarannya kelompok maupun individual, terdapat alokasi waktu dan mencantumkan sumber. Terdapat penilaian untuk minat, sikap, dan aktivitas. Pada RPP terdapat pembukaan, inti, dan penutup. Terdapat LKS baik secara kelompok maupun individu namun tidak memuat kriteria dan cara penskorannya, serta tidak memuat tindak lanjut.

2) Mata pelajaran IPA

Pada program semester terdapat jam pelajaran, alokasi waktu, dan mencantumkan pokok bahasan. Jadwal semester memuat jumlah jam pelajaran dan memuat pokok bahasan. Komponen silabus memuat penjabaran materi, tidak secara eksplisit disebutkan strategi pembelajarannya kelompok maupun individual, terdapat alokasi waktu, dan mencantumkan sumber. Penilaian untuk minat, sikap, dan aktivitas tidak ada. RPP terdapat pembukaan, inti, dan penutup. LKS berupa tugas kelompok disiapkan sedangkan untuk tugas individu tidak disiapkan. Tindak lanjut berupa perbaikan dan pengayaan tidak ada.

d. Profil guru

Guru tetap berjumlah sepuluh orang, empat orang berkualifikasi sarjana (S1), dan enam orang berkualifikasi D2, tidak ada guru honorer. Seorang golongan IV/a, empat orang golongan III/d, tiga orang golongan III/c, dua orang golongan III/b, dan seorang guru wiyata bakti mengajar Bahasa Inggris.

e. Kesimpulan

Berdasarkan hasil observasi kelas, kelemahan guru pada kegiatan penutup, yakni tidak memberi kesempatan siswa untuk mengadakan refleksi diri. Adapun berdasarkan analisis dokumen, guru perlu meningkatkan diri dalam pembuatan LKS dan menentukan strategi pembelajaran, serta merencanakan kegiatan perbaikan dan pengayaan.

Hasil wawancara dengan kepala sekolah, sudah melaksanakan kegiatan peningkatan kemampuan guru, antara lain melalui pertemuan dengan sekolah MBS tingkat kabupaten, Kelompok Kerja Guru (KKG), kerja sama dengan LPMP Jawa Tengah. Hambatan yang ada dari diri guru sendiri yang merasa sudah puas dengan apa yang ada sekarang ini. Hal yang perlu ditingkatkan adalah memperbanyak inovasi pembelajaran dan 
penambahan sarana dan prasarana khususnya multimedia.

Kepala sekolah memandang kemampuan guru dalam pembelajaran sudah cukup dan perlu diterapkan. Pendapat kepala sekolah ini ditunjang dengan visi sekolah yang pertama, yaitu berusaha untuk melaksanakan pembelajaran dan bimbingan kepada siswa dengan menggunakan strategi dan metode yang paling cocok dan berpusat pada anak. Namun masih ada hal-hal yang harus ditingkatkan, yakni sarana prasarana multimedia yang menunjang ICT.

4. SD Virgo Maria 1 Ambarawa Jawa Tengah

a. Observasi kelas

1) Mata pelajaran Seni Musik

Pengamatan pembelajaran dilaksanakan di kelas IIIA SD Virgo Maria 1 Ambarawa Jateng. Standar kompetensi yang ingin dicapai adalah siswa dapat memainkan alat musik sederhana. Pada pendahuluan guru memberikan apersepsi, menyatakan tema pembelajaran hari itu, dan tujuan yang ingin dicapai, serta mengaitkan dengan lingkungan.

Setelah selesai tampil membawakan lagu sambil diiringi alat musik, guru menugaskan siswa secara bersama-sama memainkan alat musik sesuai dengan yang dimilikinya. Guru merangkum bersama siswa. Guru mengadakan evaluasi proses, tidak memberikan umpan balik, refleksi diri, dan tindak lanjut.

2) Mata pelajaran IPA

Pengamatan pembelajaran dilaksanakan di kelas IIIB SD Virgo Maria 1 Ambarawa. Standar kompetensi yang ingin dicapai adalah siswa mengetahui tentang cuaca. Pada pendahuluan guru memberikan apersepsi, menyatakan tema pembelajaran hari itu dan tujuan yang ingin dicapai, guru mengaitkan dengan lingkungan, serta semua siswa diajak ke luar kelas untuk mengamati cuaca hari itu.

Penerapan PAKEM belum optimal karena dalam kegiatan pembelajaran tidak semua siswa antusias dan aktif. Guru merangkum bersama siswa. Guru mengadakan evaluasi secara tertulis namun tidak memberi umpan balik. Guru memberi kesempatan siswa untuk merefleksi diri dengan mengajukan pertanyaan:"Senang tidak belajar hari ini?" Guru memberikan tindak lanjut dikaitkan dengan kehidupan sehari-hari, menugaskan siswa mengamati awan hari itu, dan menyimpulkan terjadi hujan atau tidak.

Kondisi kelas masih konvensional. Hal ini ditandai dengan tidak ada pemajangan gambar-gambar di dinding kelas. Ironisnya di dinding terdapat tempat file siswa tetapi semuanya kosong. Kursi dapat dipindahkan karena setiap siswa menduduki kursi sendirisendiri. Tidak ada sudut-sudut kelas yang dimanfaatkan untuk aktivitas belajar dan pembelajaran, serta tidak ada media dan alat peraga yang terdapat di dalam kelas, kecuali papan tulis. Jumlah siswa dalam satu kelas 38 orang, dengan dua orang guru, satu senior dan satunya lagi guru honorer yang masih dibimbing dalam membelajarkan.

b. Observasi sekolah

Terdapat pajangan dinding sekolah, geguritan, tata tertib sekolah, dan rekoleksi kelas VI, gambar-gambar karya siswa di dinding dekat pintu masuk kelas masing-masing. Perpustakaan sekolah mempunyai ruangan khusus dengan ukuran $6 \times 7 \mathrm{~m}^{2}$, jumlah koleksi terdiri dari buku paket, majalah lama, dan 800 buku cerita. Bukubuku pelajaran ada yang disimpan di pojok kelas masing-masing untuk memudahkan guru dan siswa menggunakannya. Frekuensi kunjungan 50 siswa/hari, terbanyak siswa kelas IV dan V. Sekolah berlangganan koran Kompas dan Suara Medeka. Kondisi ruangan kurang memadai untuk membaca karena kurang terang namun terdapat sudut kegiatan membaca.

Koleksi media dan alat peraga lain, di antaranya adalah TV 21" dua unit (satu diletakkan di laboratorium Bahasa dan satu di Perpustakaan, Radio Tape satu buah, Tape dua buah, OHP satu buah, Komputer 22 buah masih pentium dua dan tiga. $C D$ pembelajaran bahasa Inggris, Sains, dan Matematika. Laboratorium yang ada adalah laboratorium Bahasa dan Komputer. Adapun ruang kreatif adalah aula $\left(10 \times 18 \mathrm{~m}^{2}\right)$ digunakan untuk kegiatan sekolah dan pertemuan. Di halaman belakang terdapat patung Bunda Maria di dalam gua yang digunakan untuk berdoa bersama setiap hari Sabtu. Ruang guru luasnya $8 \times 9 \mathrm{~m}^{2}$. Sarana yang ada antara lain meja kursi guru, lemari, sebuah komputer, tempat membuat air minum, dan locker. Ruang kepala sekolah dengan ukuran 7 × 6 $\mathrm{m}^{2}$, digunakan untuk ruang tamu, ruang TU, dan ruang kepala sekolah. Sarana yang ada ialah meja tulis, lemari, kursi tamu, dan sebuah komputer.

c. Analisis dokumen

Analisis dokumen diwakili oleh dua mata pelajaran berikut.

1) Mata pelajaran Seni Musik Pada program semester terdapat jam 
pelajaran dan alokasi waktu, serta mencantumkan pokok bahasan. Jadwal semester memuat jumlah jam pelajaran dan memuat pokok bahasan. Pada komponen silabus memuat penjabaran materi, secara eksplisit disebutkan strategi pembelajarannya kelompok dan klasikal tetapi untuk strategi individual tidak dicantumkan. Selain itu, terdapat alokasi waktu dan pencantuman sumber. Penilaian untuk minat, sikap, dan aktivitas tidak ada tetapi guru menilai pengembangan diri dan pembiasaan, antara lain kedisiplinan dan tanggung jawab, kebersihan dan kerapihan, kerja sama, kesopanan, kemandirian, kerajinan, kejujuran, kepemimpinan, dan ketaatan. RPP terdapat pembukaan, inti, dan penutup. LKS disiapkan, tindak lanjut dalam bentuk perbaikan dan pengayaan tidak dicantumkan. 2) Mata pelajaran IPA

Pada program semester terdapat jam pelajaran dan alokasi waktu, serta mencantumkan pokok bahasan. Jadwal semester memuat jumlah jam pelajaran dan memuat pokok bahasan. Pada komponen silabus memuat penjabaran materi, secara eksplisit disebutkan strategi pembelajarannya kelompok dan klasikal, tetapi untuk strategi individual tidak dicantumkan, terdapat alokasi waktu dan mencantumkan sumber. Penilaian untuk minat, sikap, dan aktivitas tidak ada. RPP terdapat pembukaan, inti, dan penutup tetapi tidak mencantumkan alokasi waktu. LKS secara kelompok tidak disiapkan, terdapat tugas individu, dan kriteria penilaian tetapi cara penilaian serta tindak lanjut tidak dicantumkan. d. Profil guru

Guru tetap berjumlah 14 orang, 13 orang berkualifikasi D2, dan satu orang lulusan SPG. Empat orang bergolongan III/b, seorang bergolongan III/a, empat orang bergolongan II/c, dan lima orang bergolongan II/b. Seorang guru honorer berkualifikasi D2. Guru wiyata bakti dua orang dan alumni dari D2 PGSD Universitas Sugiyopranoto Semarang.

e. Kesimpulan

Berdasarkan hasil observasi kelas, kelemahan guru pada kegiatan penutup, yakni tidak memberi kesempatan siswa untuk mengadakan refleksi diri. Adapun berdasarkan analisis dokumen, guru perlu meningkatkan diri dalam pembuatan LKS dan menentukan strategi pembelajaran serta merencanakan kegiatan perbaikan dan pengayaan. Hasil wawancara yang dilakukan dengan kepala sekolah diketahui bahwa berbagai kegiatan sudah dilakukan untuk meningkatkan kompetensi guru di antaranya mengikutsertakan guru dalam pelatihan-pelatihan di tingkat sekolah, kecamatan, dan kegiatan yang dilaksanakan oleh yayasan Marsudi Rini bekerja sama dengan Universitas Satyawacana Salatiga dan Universitas Sugiopranoto Semarang.

Hasil penelitian ini memberi gambaran bahwa peningkatan kemampuan guru masih perlu dilakukan terutama dalam hal pelaksanaan kegiatan belajar membelajarkan. Paradigma guru tentang pembelajaran perlu diubah. Penguasaan akademik atau pengetahuan secara verbalisme bukan menjadi tujuan utama dalam pembelajaran harus dipahami oleh guru. Guru perlu mengupayakan bagaimana meng-optimalkan keaktifan siswa dalam pembelajaran dan merancang pembelajaran yang bermakna bagi siswa. Kegiatan pembelajaran dapat mengembangkan potensi siswa secara optimal sehingga apa yang dipelajari di sekolah dapat diimplementasikan secara kontekstual dalam kehidupan sehari-hari siswa.

\section{KESIMPULAN}

\section{Kesimpulan}

Berdasarkan hasil dan pembahasan yang diuraikan pada Bab IV di atas maka dapat diambil kesimpulan sebagai berikut.

1. Pada beberapa sekolah, kegiatan belajar membelajarkan yang digunakan guru dalam mengembangkan PAKEM sudah ada yang mendorong siswa untuk berperan aktif, misalnya dalam membuat alat musik sederhana dan membuat baling-baling. Ada yang mengajak siswa untuk berkunjung ke luar kelas namun siswa hanya diberi tugas untuk mengamati cuaca saat itu. Diskusi kelompok jika ada hanya mempresentasikan hasil secara sederhana.

2. Alat bantu atau sumber belajar yang diperlukan guru dalam mengembangkan PAKEM belum beragam, bahkan ada yang hanya berbekal buku sumber.

3. Pemilihan metode pembelajaran guru dalam mengembangkan PAKEM masih tradisional, dalam arti guru masih cenderung menggunakan metode ceramah, tanya jawab, dan pemberian tugas.

4. Pengalaman belajar yang diperoleh siswa masih ditentukan oleh guru. Masih sedikit guru memberi kesempatan pada siswa untuk mengungkapkan gagasannya secara lisan maupun tulisan. Diskusidiskusi kelompok belum terlihat secara optimal pada setiap kelas. Hal ini dikarenakan jumlah siswa 
tiap kelas relatif masih $>40$ orang.

5. Pemilihan bahan ajar yang dilakukan guru mengacu pada buku paket yang digunakan sekolah, siswa tidak dikelompokkan sesuai dengan tingkat kemampuan, dan masih belum adanya kesadaran guru untuk menyiapkan bahan remedial maupun pengayaan.

6. Pendekatan pembelajaran yang digunakan guru dalam mengembangkan PAKEM masih sedikit yang bersifat kontekstual. Guru masih belum optimal mengaitkan pelajaran dengan kehidupan nyata siswa.

7. Penilaian guru pada pembelajaran di empat sekolah yang terpilih sebagai subjek penelitian belum sepenuhnya dilakukan secara autentik assesment. Ada yang menitikberatkan pada penilaian proses tanpa melakukan penilaian akhir pembelajaran, dan ada juga yang melakukan penilaian secara kelompok.

Berdasarkan uraian di atas, dapat disimpulkan bahwa hasil observasi yang dilakukan terhadap pembelajaran di kelas, menunjukkan masih banyaknya pendekatan konvensional, yaitu yang masih berpusat pada guru. Pada kelas tersebut situasi kelas belum mencirikan PAKEM. Dinding kelas pada umumnya tidak ada pemajangan hasil karya siswa, tidak ada pemanfaatan pojok kelas sebagai sumber belajar, metode yang digunakan masih cenderung ceramah, dan belum dimanfaatkan lingkungan sebagai sumber belajar. Demikian pula halnya dengan belajar kelompok, belajar mandiri, dan belajar menemukan (problem-based learning) sendiri belum dilaksanakan secara optimal.

\section{Implikasi}

Peningkatan kemampuan guru sekolah dasar dalam menerapkan PAKEM diperlihatkan dengan berbagai kegiatan yang terjadi selama kegiatan belajar membelajarkan. Jika guru diberi penyegaran tentang metodologi pembelajaran, bagaimana guru memilih strategi atau pendekatan atau metode yang dipraktikkan maka gambaran penerapan PAKEM di sekolah akan mengalami kemajuan. Titik berat penerapan PAKEM tersebut dapat ditinjau berdasarkan beberapa komponen pembelajaran, yakni sebagai berikut.

1. Kegiatan Belajar Membelajarkan (KBM) dilakukan secara interaktif, inspiratif, menantang, memotivasi siswa, melalui percobaan, diskusi, dan eksplorasi ke luar kelas.

2. Alat bantu serta sumber belajar diarahkan pada aneka sumber. Siswa dapat menggunakan sumber belajar dari lingkungan dengan menerapkan prinsip alam takambang, guru menjadikan alam dalam lingkungan sekitar sebagai sumber belajar dan tempat berguru.

3. Metode pembelajaran, guru memberi kesempatan kepada siswa untuk mengembangkan pengetahuan, keterampilan, dan sikap melalui percobaan, pengamatan, eksplorasi, memecahkan masalah dalam kehidupan, serta melaporkan hasil karya dengan kata-kata sendiri.

4. Pengalaman belajar siswa dilakukan melalui diskusi, mengungkapkan gagasan sendiri baik secara lisan maupun tulisan.

5. Memilih bahan ajar yang sesuai dengan kemampuan dan karakteristik siswa.

6. Memilih pendekatan yang sesuai dengan konteks materi yang akan diajarkan.

7. Mengadakan penilaian proses dan hasil pembelajaran menggunakan alat penilaian yang beragam.

\section{Saran}

Berdasarkan hasil penelitian dan pembahasan, dapat diberikan saran-saran sebagai berikut.

1. Dipertimbangkan pengkajian lanjutan tentang penerapan PAKEM yang meliputi SD yang lebih luas.

2. Dilakukannya uji kemampuan penerapan PAKEM pada sekolah terpilih dengan mengambil contoh dari kasus yang dinilai telah berhasil dengan menggunakan instrumen penilaian.

3. Ditingkatkannya pelatihan PAKEM bagi guru SD dilanjutkan dengan adanya buku panduan dan pedoman lebih lanjut mengenai penerapan berbagai strategi pembelajaran sebagai perwujudan penerapan PAKEM di kelas.

4. Tenaga kependidikan perlu diberdayakan melalui peningkatan kemampuan metodologi pembelajaran secara holistik dalam usaha peningkatan mutu proses pembelajaran.

5. Sertifikasi guru hendaknya didasarkan pada penilaian atas pelaksanaan indikator kemampuan penerapan PAKEM.

\section{DAFTAR PUSTAKA}

Anon. (2006). Materi pelatihan MBS. Jakarta: Dirjen Pendidikan Dasar dan Menengah, Depdiknas.

Bogdan, R.C. \& Biklen, S.K. (1982). Qualitative research for education. Boston, MA: Allyn and Bacon.

Creswell, J.W. (1998). Qualitative inquiry and research design. London: Sage.

Denzin, N.K. \& Lincoln, Y.S. (1994). The landscape of 
qualitative reseach. London: Sage Publications. Dryden, G. (2000). Revolusi cara belajar. Bandung: Kaifa. Johnson, E.B. (2002). Contextual teaching and learning, what it is and why it's here to stay. Thaousand Oaks: Corwin Press, Inc.

Kockelmans, J.J. (1967). Edmund husserl's, phenomonological psychology. A historica critical study. Pittsburgh: Dequesne Univ. Press.

Kratf, N. (2000). Criteria for authentic project-based learning. Denver: RMC Research Corporation.

Owen, P.M. (2007). Integrating Katz and Chard's Project Approach with Multicultural Education in the University Classroom dalam Journal of early childhood teacher education, volume 28, Juli 2007. USA: Mount Vernon Nazerene University.

Pancamegawani. (2006). Pembelajaran berbasis karakter. Makalah disampaikan pada seminar HIMPAUDI, Jakarta.
Semiawan, C. (1999). Dimensi kreatif dalam filsafat imu. Bandung: Remaja Rosdakarya.

Slamet. (2007). Pelangi Indonesia. (http:// pelangi.ditplp.go.id/artikelmbs.htm).

Sowars, Jayne. (2000). Language arts in early education. United States: Delmar Thomson Learning.

\section{KETERANGAN PENULIS}

Dra. Maratun Nafiah, M.Pd., dilahirkan di Temanggung, Februari 1962. Dra Gusti Yarmi, M.Pd. dilahirkan pada bulan Agustus 1967. Drs. Dudung Amir Soleh M.Pd, dilahirkan pada bulan April 1966. Pada saat ini menjabat sebagai dosen PGSD di FIP UNJ. 